\title{
KEBIJAKAN HUKUM PERUBAHAN BATASAN MINIMAL UMUR PERNIKAHAN PERSPEKTIF HUKUM ISLAM
}

\author{
Aristoni Aristoni \\ Fakultas Syariah, IAIN Kudus, Kudus \\ aristoni@iainkudus.ac.id
}

\begin{abstract}
Abstrak
Tulisan artikel ini bertujuan menjelaskan tentang konsep umur pernikahan dalam hukum Islam dan hukum nasional, kebijakan hukum Undang-Undang Nomor 1 Tahun 1974 dalam lintasan sejarah, pengaturan batasan minimal umur pernikahan dalam UndangUndang Perkawinan, dan kebijakan hukum perubahan batasan umur pernikahan dalam pandangan hukum Islam. Tulisan artikel ini dapat dikategorikan sebagai jenis riset kepustakaan dengan menggunakan metode penelitian kualitatif sebagai basisnya. Hasil kajian penelitian menunjukkan bahwa ketentuan umur perkawinan baik dalam hukum Islam maupun hukum nasional masing-masing terjadi perbedaan utamanya dalam penentuan batas ukuran kedewasaan. Perbedaan batas ukuran kedewasaan dalam hukum Islam terjadi karena secara eksplisit Al-Qur'an tidak menjelaskannya, sedangkan perbedaan ketentuan umur kedewasaan seseorang dalam hukum nasional disebabkan salah satu adalah lemahnya koordinasi dan pelibatan berbagai pihak dalam pembentukan peraturan perundang-undangan. Kebijakan hukum mengenai Undang-Undang Nomor 1 Tahun 1974 sejak awal hakikatnya diarahkan untuk mengadakan unifikasi hukum dalam permasalahan hukum perkawinan yang beragam dan berlaku bagi masyarakat Indonesia tanpa menghilangkan kebhinekaan yang didasarkan pada falsafah Pancasila dan Undang-Undang Dasar NRI Tahun 1945. Pengaturan perubahan batasan minimal umur perkawinan dengan segala tujuan yang positif hakikatnya memberikan jaminan keadilan, kepastian, dan kemanfaatan dari tujuan hukum diciptakan. Kebijakan hukum perubahan batasan minimal umur pernikahan dengan menyamakan umur pernikahan antara laki-laki dan perempuan 19 Tahun dalam pandangan hukum Islam dapat dikatakan bernilai kemaslahatan yaitu menjaga keberadaan jiwa, keturunan, dan akal (maqashid syariah) dan menghindarkan perempuan dari bahaya kerusakaan (mazharat) yang lebih besar akibat perkawinaan usia anak sebagaimana tertuang dalam konsideran Undang-Undang Nomor 16 Tahun 2019 tentang Perkawinan.
\end{abstract}

Kata Kunci: Kebijakan Hukum; Pernikahan; Umur Pernikahan; Hukum Islam. 


\title{
LEGAL POLICY TO CHANGE THE MINIMUM AGE LIMITS OF MARRIAGE ISLAMIC LAW PERSPECTIVE
}

\begin{abstract}
The purpose of this article is to explain the concept of the age of marriage in Islamic law and national law, the legal policy of Law No.1 of 1974 in historical trajectories, the regulation of the minimum age limit for marriage in the Marriage Law, and the legal policy to change the age limit of marriage from the Islamic Law perspective. The writing of this article can be categorized as a type of library research using qualitative research methods as its basis. The results of the research study indicate that the requirements for the age of marriage in both Islamic law and national law have major differences in determining the size limit for maturity. The difference in the size limit of maturity in Islamic law occurs because the Qur'an does not explicitly explain it, while the difference in the provisions of a person's age at maturity in national law is due to one of the reasons for the lack of coordination and involvement of various parties in the formation of statutory regulations. Since the beginning, the legal policy regarding Law Number 1 of 1974 has been essentially directed at holding legal unification in various marriage law issues and applies to the Indonesian people without eliminating diversity by the philosophy of Pancasila and the 1945 Constitution of the Republic of Indonesia. Regulations for changing the minimum age limit of marriage with all positive goals essentially guarantee justice, certainty, and benefit from the purpose of the law being created. The legal policy to change the minimum age limit of marriage by equalizing the age of marriage for men and women 19 years in the view of Islamic law can be said to be of benefit, namely maintaining the existence of the soul, descent, and reason (maqasid sharia) and preventing women from more dangerous damage (mazharat) large due to child marriage as stated in the preamble to Law Number 16 of 2019 concerning Marriage.
\end{abstract}

Keywords: Legal Policy; Marriage; Age of Marriage; Islamic Law. 


\section{A. PENDAhULUAN}

Sejarah hukum mencatat bahwa dinamika hukum perkawinan di Indonesia selalu diwarnai dengan keterlibatan kepentingan agama, negara, dan perempuan. Keterlibatan kepentingan agama didasarkan bahwa agama merupakan institusi yang memiliki kepentingan untuk mengadakan keluarga. ${ }^{1}$ Makna keluarga dalam agama hakikatnya merupakan kelompok sosial terkecil yang berperan dalam mengamalkan ajaran agama, misalnya mayoritas masyarakat Indonesia yang memeluk agama Islam berupaya memasukkan ajaran agama sebagai hukum perkawinan nasional. Sedangkan negara sebagai institusi berupaya menjamin pelaksanaan ajaran agama dan menciptakan ketertiban masyarakat. ${ }^{2}$ Jaminan negara terhadap penerapan ajaran masing-masing agama diatur di dalam Pasal 29 ayat(2) Undang-Undang Dasar NRI Tahun $1945 .^{3}$ Disisi lain, keterlibatan perempuan dalam hukum perkawinan yang sejak kemerdekaan berjuang adalah untuk memperoleh perlindungan hukum dan hakhak konstitusionalnya. ${ }^{4}$

Sejak disahkan sebagai hukum pernikahan nasional, Undang-Undang No 1 Tahun 1974 dalam perjalanannya tak pelak menuai beragam kritik sebab terdapat beberapa pasal yang mana dianggap sudah tidak lagi sejalan dengan perkembangan dan kebutuhan hukum masyarakat, salah satunya yakni Pasal 7 ayat (1) mengenai batasan umur pernikahan. Sehingga sebagian masyarakat terutama kalangan aktivis perempuan menghendaki perubahan. ${ }^{5}$

Ketentuan Pasal 7 ayat $(1)^{6}$ mengatakan bahwa "Perkawinan hanya diizinkan jika pihak pria sudah mencapai umur 19 tahun dan pihak wanita sudah mencapai 16 tahun", dalam pelaksanaanya menyisakan berbagai permasalahan diantaranya praktik perkawinan anak. Batasan umur minimal perkawinan 16 tahun bagi wanita tersebut

\footnotetext{
${ }^{1}$ Agus Hermanto, "Rekontruksi Undang-Undang Perkawinan Di Indonesia Dan Keadilan Gender" (IAIN Raden Intan Lampung, 2017), hal. 161.

${ }^{2}$ Nafi Mubarok, "Sejarah Hukum Perkawinan Islam Di Indonesia”, Al-Hukama 2 (2), 2012: hal. 140.

${ }^{3}$ Amir Syarifuddin, "Hukum Perkawinan Islam Di Indonesia; Antara Fiqh Munakahat Dan Undang-Undang Perkawinan”, Kencana, 2009, Jakarta, hal. 22-23.

${ }^{4}$ Heru Susetyo, “Revisi Undang-Undang Perkawinan”, Lex Jurnalica 4 (2), 2007: hal. 70.

${ }^{5}$ Bani Syarif Maula, "Perlindungan Perempuan Dalam Hukum Perkawinan Di Indonesia: Wacana Pembaharuan Undang-Undang Perkawinan Dalam Masalah Batas Usia Perkawinan”, Jurnal Studi Islam, Gender dan Anak 14 (1), 2019: hal. 16, https://doi.org/10.24090/yinyang.v14i1.2019.pp14-38.

${ }^{6}$ Undang-Undang Republik Indonesia, "Undang-Undang Republik Indonesia Nomor 1 Tahun 1974 Tentang Perkawinan" (1974).
} 
e-ISSN : 2621-4105

secara empiris membuka peluang perkawinan usia anak dan membuat kekhawatiran banyak pihak mengenai dampak buruknya seperti perceraian, kekerasan fisik maupun batin, kekerasan seksual, menimbulkan penyakit HIV/AIDS, kekerasan reproduksi dan kematian ibu dan bayi. ${ }^{7}$ Sederet dampak buruk akibat perkawinan usia anak tersebut dikarenakan belum memiliki kesiapan matang jiwa dan raga, dan terlebih dalam soal ekonomi. ${ }^{8}$

Pasal 7 ayat (1) juga dinilai mengandung unsur diskriminasi terhadap perempuan, ${ }^{9}$ dan secara hierarki berlawanan dengan Pasal 28 ayat (2) UndangUndang Dasar NRI Tahun 1945 yang menolak segala bentuk diskriminasi. ${ }^{10} \mathrm{Di}$ samping itu, Pasal 7 ayat (1) juga dinilai melanggar hak setiap orang sebagaimana diatur pada Pasal 27 ayat (1) Undang-Undang Dasar NRI Tahun 1945, seperti hak pendidikan, hak kesehatan, hak ekonomi, hak pilitik, hak sosial budaya, dan hak persamaan kedudukan dalam hukum. ${ }^{11}$ Atas dasar inilah Undang-Undang No 1 Tahun 1974 diajukan judicial review ke Mahkamah Konstitusi RI oleh masyarakat. ${ }^{12}$

Disahkannya Undang-Undang No 16 tahun 2019 tentang Perubahan Atas Undang-Undang No 1 Tahun 1974 tentang Perkawinan menjadi catatan sejarah tersendiri dalam perkembangan dan pembaharuan hukum pernikahan di Indonesia. Sebagaimana dalam konsideran dijelaskan bahwa Undang-Undang Perkawinan baru ini lahir sebagai pelaksana Putusan Mahkamah Konstitusi Republik Indonesia Nomor 22/PUU-XV/2017. Sebelumnya, dalam salah satu amar putusan tersebut menyatakan bahwa "mengamanatkan kepada pembentuk Undang-Undang dalam waktu tiga (3) tahun untuk melakukan perubahan terhadap Undang-Undang No 1 Tahun 1974 tentang Perkawinan".

\footnotetext{
${ }^{7}$ Habib Shulton Asnawi, "Tinjauan Kritis Terhadap Hak-Hak Perempuan Dalam UU. No. 1 Tahun 1974 Tentang Perkawinan: Upaya Menegakkan Keadilan Dan Perlindungan HAM Perspektif Filsafat Hukum Islam, ” Jurnal Fikri 1 (1), 2016, hal. 42.

${ }^{8}$ Yusuf, "Dinamika Batasan Usia Perkawinan di Indonesia: Kajian Psikologi dan Hukum Islam" JIL : Journalof Islamic Law 1 (1), 2020: 22, https://doi.org/10.24260/jil.v1i2.59.

${ }^{9}$ Burhanuddin ABD. Gani, "Perubahan Batas Usia Kawin Dalam Putusan Mahkamah Konstitusi Nomor 22/PUU-XV/2017 Di Lihat Dari Penerapan Maqasid Asy-Syari'ah”, LKKI Publisher Fakultas Syariah dan Hukum, UIN Ar-Raniry, 2020, Banda Aceh, hal.4.

${ }^{10}$ Jordy Herry Christian and Kirana Edenela, "Terampasnya Hak-Hak Perempuan Akibat Diskriminasi Batas Usia Perkawinan”,Lex Scientia Law Review 3(1), 2019, hal. 2.

${ }^{11}$ Christian and Edenela, hal. 2.

${ }^{12}$ Novita Lestari, "Problematika Hukum Perkawinan Di Indonesia”, Jurnal Ilmiah Mizani: Wacana Hukum, Ekonomi dan Keagamaan 4 (1), 2018, hal. 146, https://doi.org/10.29300/mzn.v4i1.1009.
} 
Amar putusan sebagaimana telah disinggung di atas, pada dasarnya merupakan mandat konstitusional yaitu mendukung kebijakan hukum (legal policy) dalam rangka pembangunan hukum yang diarahkan guna memberikan proteksi hukum pada perempuan serta pencegahan praktik perkawinan anak dan eksploitasi anak. Dikabulkannya sebagian permohonan uji materiil oleh Mahkamah Konstitusi harus dipahami sebagai indikator perkembangan ketatanegaraan yang progresif dan responsif dimana merefleksikan adanya penguatan prinsip dalam negara hukum terutama terkait merespon perkembangan zaman dan kebutuhan hukum masyarakat seiring dengan perubahan sosial. ${ }^{13}$

Penelitian yang mengkaji tentang batasan usia perkawinan sudah banyak dilakukan baik dalam bentuk penelitian normatif maupun empiris. Indrawati $(2020)^{14}$ dalam penelitianya mengatakan bahwa diubahnya ketentuan batasan umur pernikahan hakikatnya berorientasi pada upaya pencegahan perkawinan di bawah umur. Syaifullah $(2015)^{15}$ hasil penelitianya menunjukkan bahwa fenomena praktik perkawinan di usia belum matang khususnya perempuan di pedesaaan disebabkan adanya intervensi keluarga (orang tua) yang mengingkan agar anaknya menikah dengan laki-laki yang lebih mapan dalam segi ekonomi. Praktik tersebut menurut Syaifullah dinilai mendudukkan perempuan dalam posisi terdiskriminasi, hal ini terjadi karena perempuan selama ini dipahami sebagaisubordininasi.

Ilham Hidayatullah et al. $(2018)^{16}$ dalam penelitiannya mengatakan bahwa pandangan masyarakat desa tentang pernikahan dapat berimplikasi terhadap meningkatnya pernikahan anak. Realitas tersebut menafikan hak perempuan yang semestinya juga memiliki peluang yang sama sebagaimana laki-laki melalui nilai dan penormaan dalam menentukan umur pernikahan. Selanjutnya, penelitian yangr dilakukan Sholehudin $(2019)^{17}$, hasil penelitian menunjukkan bahwa unsur

${ }^{13}$ MD Mahfud, “Politik Hukum Di Indonesia”, Pustaka LP3ES, 1998, Jakarta, hal. 8.

${ }^{14}$ Septi Indrawati and Agus Budi Santoso, "Perspektif Undang-Undang Nomor 16 Tahun 2019 Tentang Perkawinan Terhadap Batas Usia Melakukan Perkawinan” Amnesti, Jurnal Hukum 2 (1), 2020.

${ }^{15}$ Shafiyullah, "Hak Usia Perkawinan Bagi Perempuan (Perspektif Hukum Islam dan Gender)," Yinyang Jurnal Studi Islam, Gender, dan Anak 10 (1), 2015.

${ }^{16}$ Ilham Hidayatulloh et al., "Persepsi Perkawinan Usia Dini Dan Pemberdayaan Gender (Studi Kasus Desa Pancawati Kecamatan Caringin Kabupaten Bogor)," Sosioglobal: Jurnal Pemikiran Dan Penelitian Sosiologi 3(1), 2018: 1, https://doi.org/10.24198/jsg.v3i1,18148.

${ }^{17}$ Miftahus Sholehudin, "Legislasi Pendewasaan Usia Perkawinan Alternatif Perpsektif Hukum Adat Dalam Pembangunan Hukum Nasional”, Jurnal Hukum Samudra Keadilan 14(1), 2019, hal 1-14, https://doi.org/10.33059/jhsk.v14i1.1081. 
e-ISSN : 2621-4105

kedewasaan dalam perkawinan menjadi syarat intrinsik dan berpengaruh terhadap kelangsungan dalam perkawinan, meskipun unsur tersebut tidak menempati syarat sah dalam perkawinan. Sehubungan dengan hal ini, konfigurasi politik sebagaimana tertuang dalam produk hukum memiliki variasi yang kompleksitas sehingga dapat berpengaruh pada ukuran kedewasaan seseorang berdasarkan peran serta kepentingan anak sebagai subyek hukum.

Beberapa hasil penelitian sebelumnya di atas sesungguhnya memiliki korelasi dengan penelitian ini yaitu yang sama-sama membahas mengenai batasan usia perkawinan. Perbedaanya adalah penelitian ini lebih menfokuskan kajian pada ranah kebijakan hukum pembentuk Undang-Undang dalam penetapan penyamaan batasan minimal umur pernikahan laki-laki dan wanita dilihat dari sudut pandang hukum Islam. Sehingga kajian penelitian ini melengkapi dari penelitian sebelumnya. Selanjutnya, penelitian ini bertujuan untuk menjelaskan tentang konsep umur pernikahan dalam hukum Islam dan hukum nasional, kebijakan hukum pembentukan Undang-Undang No 1 Tahun 1974 dalam lintasan sejarah, pengaturan batasan umur pernikahan dalam Undang-Undang Perkawinan, kebijakan hukum perubahan batasan umur pernikahan dalam perspektif hukum Islam.

\section{B. PERMASAlahaN}

Berpijak dari latar belakang di atas, maka dapat dirumuskan beberapa permasalahan diantaranya : 1) Bagaimanakah konsep umur pernikahan dalam hukum Islam dan hukum nasional? 2) Bagaimanakah kebijakan hukum Undang-Undang No.1 Tahun 1974 dalam lintasan sejarah? 3) Mengapa diperlukan pengaturan batasan minimal umur pernikahan dalam Undang-Undang Perkawinan? 4) Bagaimanakah kebijakan hukum perubahan batasan minimal umur pernikahan menurut pandangan hukum Islam?

\section{METODE PENELITIAN}

Tulisan artikel ini dapat disebut sebagai jenis riset kepusatakaan dengan digunakannya pendekatan kualitatif sebagai basisnya. Dalam kajian pembahasan menggunakan pendekatan yuridis normatif berupa hukum Islam dan peraturan perundang-undangan. Pendekatan yuridis normatif ini digunakan untuk menelaah dan menganalisa berbagai teks dan peraturan perundang-undangan yang berkaitan dengan 
e-ISSN : 2621-4105

perubahan batasan umur perkawinan. Sesuai dengan pendekatannya, maka sumber data yang digunakan dalam riset ini berupa data sekunder yang terdiri dari bahan hukum primer, bahan hukum sekunder, dan bahan hukum tersier. Bahan hukum primer yang digunakan adalah Undang-Undang No 16 Tahun 2019 jo UndangUndang No 1 Tahun 1974 tentang Perkawinan, dan peraturan hukum lainnya yang masih ada relevansinya dengan tema riset ini. Bahan hukum sekunder adalah "bahan hukum yang digunakan sebagai penunjang atau penjelas bahan hukum primer". Diantara bahan hukum sekunder tersebut antara lain buku-buku, artikel jurnal, majalah, dan lain sebagainya. Sedangkan bahan hukum tersier yang digunakan dalam kajian penelitian ini adalah ensiklopedia, kamus hukum maupun kamus lainnya yang masih ada relevansi dengan penelitian ini. Selanjutnya, semua data yang telah dikumpulkan kemudian dilakukan analisis dengan metode kualitatif yang bersifat diskriptif. Tujuan penggunaan teknik analisis data ini adalah untuk mendiskripkan dan menganalisa kebijakan hukum mengenai perubahan batasan minimal umur pernikahan dalam pandangan hukum Islam.

\section{HASIL DAN PEMBAHASAN}

\section{Konsep Umur Pernikahan dalam Hukum Islam dan Hukum Nasional}

Kajian dan perkembangan hukum perkawinan terutama mengenai batasan umur perkawinan sampai saat ini masih menarik untuk diperbincangankan mengingat batasan umur dalam perkawinan memiliki implikasi hukum bagi suamiistri dalam membangun keluarga yang kekal dan tertram. Oleh sebab itu, dalam perkembanganya banyak yang menjadikan umur menjadi salah satu aspek penting dalam merealisasikan tujuan perkawinan. ${ }^{18}$ Salah satu diantara tujuan pernikahan ialah untuk memliki keturunan dan melestarikan kehidupan manusia. ${ }^{19}$

\section{Umur Pernikahan Menurut Hukum Islam}

Hakikat Islam sesungguhnya agama yang universal dimana mengatur berbagai aspek kehidupan manusia termasuk dalam bidang pernikahan (perkawinan). Meskipun demikian, segala persoalan perkawinan tidak semuanya dijelaskan secara eksplisit oleh Al-Qur'an maupun Hadis, misalnya tentang batasan umur perkawinan. Islam hanya mensyaratkan perkawinan bagi seseorang

\footnotetext{
${ }^{18}$ Gani, "Perubahan Batas Usia Kawin Dalam Putusan Mahkamah Konstitusi Nomor 22/PUUXV/2017 Di Lihat Dari Penerapan Maqasid Asy-Syari'ah,” hal. 19.

${ }^{19}$ Lestari, "Problematika Hukum Perkawinan di Indonesia," hal. 50.
} 
adalah sudah dewasa (balig). ${ }^{20}$ Ini artinya anak yang sudah baligh dianggap telah dewasa dan diperbolehkan untuk dinikahkan oleh orang tuanya, seperti yang diungkapkan Asghar Ali (1994) yaitu disaat anak sudah mulai menginjak usia dewasa, maka seorang anak diperbolehkan untuk meneruskan dan membatalkan ikatan perkawinan. Kedewasaaan menurutnya didasarkan pada kemampuan (ahliyyah) seseorang dalam melakukan tindakan hukum. Ia menambahkan bahwa dalam Al-Qur'an sendiri tidak ada ketentuan tentang pernikahan anak-anak dan patokan umur pernikahan yang dijadikan sebagai dasar larangan bagi anak untuk dinikahkan. $^{21}$

Kedewasaan (baligh) dalam Islam ditandakan dengan ketentuan apabila lakilaki telah bermimpi basah dan perempuan sudah pernah haid. Seiring perkembanganya konsep kedewasaan mengalami perdebatan dikalangan ulama fikih. Hal ini disebabkan sulitnya menentukan batasan dan ukuran kedewasaan sebagai syarat penting dalam perkawinan. Menurut Imam Syafi'i bahwa seorang ayah dan kakek disunnahkan menikahkan anak gadisnya kecuali ia sudah baligh, dengan persyaratan mendapatkan izin dari seorang anak agar tidak terjebak dalam tawanan suaminya. ${ }^{22}$

Sedangkan menurut Abu Hanifah bahwa selain ayah dan kakek, para wali lainnya diperbolehkan menikahkan seorang anak gadisnya dan perkawinan tersebut adalah sah, akan tetapi harus seizin dari anak. Pandangan ini tampaknya berbeda dengan Hammad, Urwah, dan Syuraih yang mengatakan bahwa seorang anak gadis diperbolehkan dinikahkan walinya meskipun belum dewasa (baligh). Pendapat tersebut diriwayatkan oleh Al-Khathabi dari Imam Malik. ${ }^{23}$ Namun ketika anak sudah mulai menginjak masa usia dewasa (baligh), maka diperbolehkan meneruskan atau mengakhiri pernikahan. Kebolehan tersebut bersifat mutlak dan seorang pun tidak boleh mengintervensi termasuk orang tua atau kerabatnya. Namun kebolehan untuk meneruskan dan memutuskan ikatan

\footnotetext{
${ }^{20}$ Khoirul Abror, "Hukum Perkawinan Dan Perceraian", Ladang Kata, 2020, Yogyakarta, hal. 106.

${ }^{21}$ Asghar Ali Engineer, "Hak-Hak Perempuan Dalam Islam", Yayasan Bentang Budaya, 1994, Yogyakarta, hal. 94.

${ }^{22}$ Gani, "Perubahan Batas Usia Kawin Dalam Putusan Mahkamah Konstitusi Nomor 22/PUUXV/2017 Di Lihat Dari Penerapan Maqasid Asy-Syari'ah," hal. 21.

${ }^{23}$ Gani, hal. 28.
} 
perkawinan menurut Khoiruddin Nasution terdapat ketentuan syarat yang mana diantara keduanya belum pernah melakukan hubungan seksual. ${ }^{24}$

Perbedaan pendapat dikalangan ulama fikih di atas dikarenakan Al-Qur'an secara eksplisit tidak menjelaskan terkait kedewasaan dan umur ideal dalam perkawinan. Islam hanya menggariskan kedewasaan seseorang dari sisi baligh. Namun yang menjadi masalah adalah sejauh ini belum terdapat definisi kewedasaaan yang merepresentasikan sekian indikator karakteristik seseorang untuk hidup berkeluarga. Sulitnya mendefiniskan ukuran kedewasaam, maka sumber ajaran Islam sebagaimana Al-Qur'an dan Hadis selain dipahami secara normatif melainkan juga harus dipahami konteksnya, artinya pemahaman secara kontektual sangat diperlukan dengan melihat perkembangan pemikiran keagamaan yang progresif guna melahirkan interpretasi keagamaan yang mampu menjawab kebutuhan kontekstual terutama yang menyangkut tentang batasan umur dalam perkawinan. ${ }^{25}$

Kedewasan yang cenderung diartikan baligh dimana laki-laki telah mimpi basah dan wanita telah menstruasi tidak menjamin seseorang tersebut memiliki kematangan dalam berpikir dan bersikap dewasa terutama dalam memikul tanggung jawab sebagai suami istri. ${ }^{26}$ Sejalan dengan hal ini, Soemiyati dalam bukunya berjudul "Hukum Perkawinan dan Undang-Undang Perkawinan Nomor 1 Tahun 1974", mengatakan bahwa umur dalam perkawinan menjadi hal yang krusial untuk merealisasikan tujuan perkawinan. Oleh karenanya suami istri haruslah sudah memiliki kematangan jiwa dan raganya. ${ }^{27}$

\section{Umur Pernikahan Menurut Hukum Nasional}

Secara yuridis, penentuan batas umur dewasa hakikatnya merupakan hal yang sangat penting mengingat usia tersebut erat kaitanya dengan kecakapan dalam bertindak dan melakukan tindakan hukum. Dalam peraturan hukum di Indonesia terdapat ketidakseragaman mengenai batasan umur dewasa. Bahkan dikalangan praktisi khususnya hakim sendiri terjadi perbedaan pendapat dalam

\footnotetext{
${ }^{24}$ Khoiruddin Nasution, "Fazlur Rahman Tentang Wanita", Tazzafa, 2002, Yogyakarta, hal. 229.

${ }^{25}$ Zaitunah Subhan, "Al-Qur'an Dan Perempuan Menuju Kesetaraan Gender Dalam Penafsiran", Kencana, 2015, Jakarta, hal. 9.

${ }^{26}$ Abror, "Hukum Perkawinan Dan Perceraian," hal. 107.

${ }^{27}$ Soemiyati, "Hukum Perkawinan Islam Dan Undang-Undang Perkawinan No. 1 Tahun 1974", Liberti, 2004, Yogyakarta, hal. 30.
} 
menentukan batasan umur seseorang ketika dijadikan sebagai saksi di persidangan. Satu pihak ada yang membolehkan saksi berumur 18 tahun, namun dilain pihak menolak sebab umur tersebut dipandang belum memiliki kecapakan dalam berpikir maupun bersikap sehingga seseorang yang menjadi saksi haruslah berumur 21 tahun. ${ }^{28}$

Menurut Oka Mahendra sebagaimana dikutip oleh Mardi Candra mengatakan bahwa "tidak ada keseragaman umur kedewasaan mengindikasikan adanya disharmoni peraturan perundang-undangan yang berdampak pada beberapa hal diantaranya terjadinya perbedaan penafsiran dan pelaksanaannya, adanya ketidakpastian hukum, peraturan hukum tidak berjalan efektif dan efisien, tidak berfungsinya hukum, artinya hukum tidak mampu memberikan pijakan berperilaku kepada masyarakat, pengendalian sosial, dan penyelesaian sengketa bahkan sebagai instrumen dalam perubahan masyarakat secara baik". ${ }^{29}$

Undang-Undang No 1 Tahun 1974 (sebelum perubahan) menyatakan bahwa batasan umur menikah untuk laki-laki sembbilan belas (19) tahun dan wanita enam belas (16) tahun (setelah perubahan laki-laki maupun wanita samasama 19 tahun). Sedangkan Undang-Undang No 23 Tahun 2002 jo UndangUndang No 35 Tahun 2014 tentang Perlindungan Anak, Pasal 1 ayat (1) mengatakan bahwa "anak adalah seseorang yang berusia di bawah 18 Tahun termasuk anak yang masih dalam kandungan”. Pada dasarnya Undang-Undang tersebut juga tidak secara jelas menyinggung terkait batasan minimum anak dalam melangsungkan pernikahan. ${ }^{30}$

Pasal 15 ayat (1) Kompilasi Hukum Islam menyatakan bahwa "untuk keselamatan keluarga dan rumah tangga perkawinan hanya boleh dilakukan calon mempelai yang telah mencapai umur yang telah ditetapkan dalam Pasal 7 Undang-

\footnotetext{
${ }^{28}$ Sudono, "Untuk Apa Kepentingan Batasan Usia Dewasa Itu”, Pengadilan Agama Blitas Kelas 1A, 2020, http://pa-blitar.go.id/pablweb/informasi-pengadilan/160-untuk-kepentingan-apa-batasan-usiadewasa-itu.html. Diakses pada tanggal 1 Februari 2021

${ }^{29}$ Mardi Candra, “Aspek Perlindungan Anak Indonesia: Analisis Tentang Perkawinan Di Bawah Umur”, Kencana, 2018, Jakarta, hal.13.

${ }^{30}$ Maula, "Perlindungan Perempuan Dalam Hukum Perkawinan Di Indonesia: Wacana Pembaharuan Undang-Undang Perkawinan Dalam Masalah Batas Usia Perkawinan,” hal. 30.
} 
Undang Nomor 1 Tahun 1974 yaitu calon suami sekurang-kurangnya berumur 19 tahun dan calon istri berumur sekurang-kurangnya 18 tahun". 31

Kitab Undang-Udang Hukum Perdata yang selanjutnya disebut KUH Perdata juga menyinggung ukuran kedewasaan seseorang selain didasarkan unsur umur juga didasarkan pada status perkawinan. Selanjutnya bagi mereka yang belum berumur 21 tahun namun telah menikah maka telah dianggap sudah dewasa. ${ }^{32}$ Undang-Undang No 39 Tahun 1999 tetang Hak Asasi Manusia, Pasal 1 ayat (5) mengatakan bahwa "anak adalah setiap manusia yang berusia di bawah 18 tahun dan belum menikah termasuk anak yang masih dalam kandungan apabila hal tersebut adalah demi kepentingannya".

Perbedaan dalam menafsirkan batasan umur dewasa sebagaimana dalam peraturan perundang-undangan akan menimbulkan permasalahan dalam pelaksanaannya. Menurut pendapat Mardi Candra bahwa beberapa hal yang melatarbelakangi terjadinya perbedaan mengenai pengaturan batasan umur dewasa seseorang yaitu: 1) dalam pembentukan peraturan hukum (Undang-Undang) dilakukan oleh institusi yang berbeda dan cenderung juga dalam waktu yang berbeda pula; 2) pejabat yang memiliki kewenangan sebagai pembentuk peraturan perundang-undangan sering berganti-ganti dikarenakan adanya batasan waktu masa jabatan atau alih tugas; 3) pendekatan sistem lemah dalam pembentukan regulasi dibanding pendekatan sektoral; 4) lemahnya koordinasi dan pelibatan berbagai pihak dalam pembentukan peratuan perundang-undangan; 5) terbatasnya peran warga dalam akses pembuatan hukum. ${ }^{33}$

\section{Kebijakan Hukum Undang-Undang No 1 Tahun 1974 dalam Lintasan} Sejarah

Menurut sejarahnya, Undang-Undang No 1 Tahun 1945 tentang Perkawinan lahir di era pemeritahan orde baru. Sebelum Undang-Undang ini disahkan sebagai Undang-Undang Perkawinan yang berlaku secara nasional, dalam konteks hukum perkawinan di Indonesia terdapat beberapa sistem hukum

\footnotetext{
${ }^{31}$ Instruksi Presiden, "Instruksi Presiden Nomor 1 Tahun 1991 Tentang Kompilasi Hukum Islam" (1991).

${ }^{32}$ Sanawiah and Muhamad Zainul, "Batasan Kedewasaan Dan Kecakapan Hukum Pewasiat Menurut KHI Dan KUH Perdata”, Jurnal Hadratul Madaniyah 5 (1), 2018, hal. 7. 12.

${ }^{33}$ Candra, "Aspek Perlindungan Anak Indonesia: Analisis Tentang Perkawinan Di Bawah Umur,"
} 
perkawinan yang berlaku diantaranya 1) untuk masyarakat yang beragama Islam berlaku padanya Hukum Islam, 2) bagi umat kristen berlaku ordonansi hukum perkawinan Kristen yang berlaku di Jawa, Ambon, dan Minahasa, 3) hukum adat berlaku bagi penduduk Indonesia asli, 4) bagi keturunan Timur Asing Cina dan golongan Eropa berlaku KUHPerdata, dan 5) bagi penduduk yang melakukan perkawinan campuran berlaku hukum perkawinan campuran. ${ }^{34}$

Membincang proses pembentukan Undang-Undang Perkawinan dalam lintasan sejarah sesungguhnya tidak memakan waktu yang cukup lama, proses pembentukan sampai dengan pengesahan memakan waktu sekitar enam (6) bulan terhitung dari mulai bulan Juli 1974 sampai bulan Januari 1974 atau tepatnya saat proses penyerahan naskah Rancangan Undang-Undang Perkawinan dari Presiden kepada Dewan Perwakilan Rakyat, kemudian dari pimpinan Dewan Perwakilan Rakyat yang dibagikan kepada anggota DPR hingga sampai pengesahan menjadi Undang-Undang No 1 Tahun 1974 tentang Perkawinan. ${ }^{35}$

Proses legislasi tersebut dilakukan melalui tahapan-tahapan diantaranya yaitu tahapan I sampai Tahapan IV. Namun demikian, pada tataran pelaksanaan proses pembentukan sampai pengesahan Undang-Undang Perkawinan sebagaimana dipaparkan di atas pada faktanya tidak berjalan mulus seperti dibayangkan, melainkan diwarnai gejolak sosial-politik yang pada akhirnya bermuara pertentangan antara dua kepentingan yaitu kelompok nasionalis dan kelompok Islam. ${ }^{36}$

Kelompok nasionalis beranggapan bahwa Rancangan Undang-Undang Perkawinan telah memenuhi kemajemukan kepentingan masyarakat dengan melandaskan pada falsafah Pancaila dan Undang-Undang Dasar NRI Tahun 1945. Namun disisi lain kelompok Islam mengklaim bahwa Rancangan Undang-Undang tentang Perkawinan yang terdiri dari 15 bab dan terbagi ke dalam 73 pasal tersebut tidak merepresentasikan kepentingan kelompok Islam karena materi dari

\footnotetext{
${ }^{34}$ Aristoni and Junaidi Abdullah, "4 Dekade Hukum Perkawinan Di Indonesia: Menelisik Problematika Hukum Dalam Perkawinan Di Era Modernisasi”,'Yudisia 7 (1), 2016, hal. 83-84.

${ }^{35}$ Ahmad Rifai, Ibnu Sodiq, and Abdul Muntholib, "Sejarah Undang-Undang Perkawinan Atas Pendapat Hingga Pertentangan dari Masyarakat dan Dewan Perwakilan Rakyat Tahun 19731974”Journal of Indonesian History 4 (1), 2015, hal. 5.

${ }^{36}$ Gani, "Perubahan Batas Usia Kawin dalam Putusan Mahkamah Konstitusi Nomor 22/PUUXV/2017 di Lihat dari Penerapan Maqasid Asy-Syari'ah," hal. 18.
} 
Rancangan Undang-Undang Perkawinan dinilai banyak berlawanan dengan ajaran Islam. ${ }^{37}$ Fraksi Partai Persatuan Pembangunan diketahui sejak awal keberatan terhadap Rancangan Undang-Undang Perkawinan tersebut terus melakukan mobilisasi massa dan aksi besar-besaran mendesak pemerintah agar mengubah Rancangan Undang-Undang Perkawinan.

Menghadapi gejolak sosial dan politik yang diwarnai dengan gelombang aksi diberbagai daerah, akhirnya pemerintah berinisiatif melakukan lobi diluar sidang. ${ }^{38}$ Hasilnya tercapai kesepatan antara fraksi ABRI dan Partai Persatuan Pembangunan diantaranya, yaitu 1) Hukum agama Islam dalam perkawinan tidak akan dikurangi; 2) Undang-Undang No 22 Tahun 1946 tentang Pencatatan Nikah, Talak, dan Rujuk dan Undang-Undang No 14 Tahun 1970 tentang KetentuanKetentuan Pokok Kekuasaaan Kehakiman; 3) kehakiman yang menempatkan Pengadilan Agama sederajat dengan Pengadilan lainnya dijamin kelangsungannya; 4) hal-hal dimana berlawanan dengan ajaran Islam dan tidak mungkin disesuaikan dengan Undang-Undang ini dihilangkan. ${ }^{39}$

Setelah adanya kesepakatan, jalan terjal dalam pembahasan Rancangan Undang-Undang Perkawianan mulai lancar hingga disahkannya Undang-Undang No 1 Tahun 1974 yaitu pada tanggal 2 Januari 1974 yang selanjutnya diundangkan dalam Lembaran NRI. Sedangkan penjelasan Undang-Undang Perkawinan dimuat Tambahan Lembar Negara Nomor 3019. ${ }^{40}$ Undang-Undang ini diperkuat dengan peraturan pelaksana yaitu PP No 9 Tahun 1974 tentang Pelaksanaan UndangUndang No 1 Tahun 1974 tentang Perkawinan . Dengan disahkannya Rancangan UU Perkawianan menjadi UU Perkawinan, maka Undang-Undang tersebut menjadi bagian yang tidak terpisahkan dari sistem hukum yang berlaku bagi masyarakat Indonesia (ius constitutum), ${ }^{41}$

\footnotetext{
${ }^{37}$ Jaih Mubarok, "Pembaharuan Hukum Perkawinan Di Indonesia”, Simbiosa Rekatama Media, 2015, Bandung, hal. 31.

${ }^{38}$ Ratna Batara dan Hindun Anisah Munti, “Posisi Perempuan Dalam Hukum Islam Di Indonesia”, LKiS, 2005, Yogyakarta, hal. 13.

${ }^{39}$ Fatah Hidayat, "Dinamika Perkembangan Hukum Keluarga Di Indonesia”, Jurnal An Nisa'a 9(2),. 2014, hal. 17.

${ }^{40}$ Gani, "Perubahan Batas Usia Kawin Dalam Putusan Mahkamah Konstitusi Nomor 22/PUUXV/2017 Di Lihat Dari Penerapan Maqasid Asy-Syari'ah,” hal. 21.

${ }^{41}$ Rifai, Sodiq, and Muntholib, "Sejarah Undang-Undang Perkawinan Atas Pendapat Hingga Pertentangan dari Masyarakat Dan Dewan Perwakilan Rakyat Tahun 1973-1974” hal. 8.
} 
Menurut Daud Ali, Arah kebijakan hukum pembentukan Undang-Undang Perkawinan sesungguhnya dimaksudkan untuk mengadakan unifikasi hukum dalam permasalahan hukum perkawinan yang beragam dan berlaku bagi masyarakat hukum Indonesia tanpa menghilangkan kebhinekaan berlandaskan falsafah Pancasila dan Undang-Undang Dasar NRI Tahun 1945. Sementara itu, bagi warga negara beragama selain tunduk pada ketentuan"Undang-Undang No. 1 Tahun 1974 tentang Perkawinan juga tunduk pada ketentuan hukum agama dan kepercayaanya sepanjang belum diatur di dalam UU Perkawinan ini. ${ }^{42}$

\section{Pengaturan Batasan Minimal Umur Pernikahan dalam Undang-Undang Perkawinan}

Kebijakan hukum pembentuk Undang-Undang No 1 Tahun 1974 tentang Perkawinan sejak awal sesungguhnya bertujuan untuk mengangkat harkat dan martabat wanita dengan membedakan batasan umur pernikahan laki-laki dan wanita yang kemudian disepakati secara nasional. ${ }^{43}$ Secaara empiris pengaturan tentang batasan umur perkawinan ini didasarkan pada banyaknya terjadi kasus KDRT yang dialami perempuan sehingga berdampak pada pendidikan, kesehatan dan psikologi anak-anak mereka nantinya. ${ }^{44}$

Kenyatan di atas selanjutya menjadi pertimbangan bagi pembuat kebijakan dalam merumuskan Pasal 7 ayat (1) UU No. 1 Tahun 1974 Pengaturan batasan umur pernikahan sebagaimana pasal tersebut yaitu "laki-laki berumur 19 tahun dan wanita 16 tahun" ketika melangsungkan perkawinan dianggap telah memiliki kematangan secara fisik maupun jiwanya dibanding ketentuan dalam hukum perdata yang menyatakan bahwa perempuan 15 tahun dan laki-laki 18 tahun. $^{45}$

Namun seiring dengan perkembangan zaman pemberlakuan Pasal 7 ayat (1) dalam pelaksanaanya memiliki banyak celah dan berpotensi memberikan peluang maraknya pernikahan usia anak dijumlah daerah di Indonesia terutama

\footnotetext{
${ }^{42}$ Muhammad Daud Ali, "Hukum Islam Dan Peradilan Agama”, Raja Grafindo Persada, 1997, Jakarta, hal. 83.

${ }^{43}$ Maula, "Perlindungan Perempuan Dalam Hukum Perkawinan Di Indonesia: Wacana Pembaharuan Undang-Undang Perkawinan Dalam Masalah Batas Usia Perkawinan," hal. 16.

${ }^{44}$ Gani, "Perubahan Batas Usia Kawin Dalam Putusan Mahkamah Konstitusi Nomor 22/PUUXV/2017 Di Lihat Dari Penerapan Maqasid Asy-Syari'ah,” hal. 21.

${ }^{45}$ Amiur Nuruddin and Azhari Akmal Tarigan, "Hukum Perdata Islam Indonesia: Studi Kritis Perkembangan Hukum Islam Dari Fikih, Undang-Undang Nomor 1 Tahun 1974 Sampai Kompilasi Hukum Islam”, Kencana, 2006, Jakarta, hal. 70.
} 
dipedesaaan dan diskriminasi terhadap perempuan. Apalagi Pasal 6 disebutkan bahwa "perkawinan sebelum usia 21 tahun harus mendapatkan izin dari orang tua". Dari ketentuan ini jelas bahwa peran orang tua sangat dominan dalam keputusan pernikahan anaknya tak terkecuali dalam perkawinan yang dilakukan pada usia anak. $^{46}$

Lahirnya Undang-Undang No 16 tahun 2019 Perubahan Atas UndangUndang No 1 Tahun 1974 tentang Perkawinan dapat dimaknai merupakan kebijakan hukum yang progresif dan responsif. Pada dasarnya pengaturan Pasal 7 ayat (1) Undang-Undang No 16 Tahun 2019 diorientasikan untuk mencegah perkawinan usia anak dan mengembalikan hak-hak perempuan secara konstitusional serta menghindarkan anak dari eksploitasi. Sehingga ketentuan Pasal 7 ayat (1) mensyaratkan batasan minimal umur pernikahan bagi laki-laki dan wanita yang akan melangsungkan perkawinan sama-sama 19 tahun. Dengan disahkannya Undang-Undang tersebut pada tanggal 14 Oktober 2019 menjadi catatan sejarah dalam pembaruan hukum perkawinan di Indonesia yang telah berumur hampir mendekati setengah abad.

\section{Kebijakan Hukum Perubahan Batasan Minimal Umur Pernikahan} Perspektif Hukum Islam

Kebijakan hukum mengenai perubahan batasan minimal umur pernikahan sebagaimana Pasal 7 ayat (1) Undaang-Undang No 1 Tahun 1974 adalah bentuk konsistensi dan keseriusan pemerintah (eksekutif dan legislatif) sebagai pembentuk Undang-Undang merespon tuntutan masyarakat yang menghendaki penghapusan segala bentuk diskriminasi dan pencegahan perkawinan usia anak dalam Undang-Undang Perkawinan.

Pasal 28b ayat (1) Undang-Undang Dasar NRI Tahun 1945 menegaskan bahwa "setiap orang berhak atas pengakuan, jaminan, perlindungan, dan kepastian hukum yang adil serta perlakuan yang sama dihadapan hukum”. Berdasarkan ketentuan tersebut, Muladi berpendapat bahwa "setiap warga negara bersama kedudukannya memiliki hak dan kewajiban yang sama baik antara laki-laki

\footnotetext{
${ }^{46}$ Badan Pusat Statistik and UNICEF Indonesia, "Perkawinan Usia Anak Di Indonesia 2013 Dan 2015, ” Revisi, Badan Pusat Statistk dan UNICEF Indonesia, 2017, Jakarta, hal. 8.
} 
maupun wanita". ${ }^{47}$ Oleh karena itu, dalam konteks bermasyakat, berbangsa, bernegara hukum, negara tidak boleh membeda-bedakan warga negara berdasarkan agama, suku, budaya, ras, jenis kelamin, status sosial dan lain sebagainya. $^{48}$

Dengan lahirnya Undang-Undang No 16 Tahun 2019 tentang Perubahan Atas Undang-Undang No 1 Tahun 1974 tentang Perkawinan terjadi perubahan yang fundamental terkait substansi hukum (materi) Pasal 7 ayat (1) yakni "penyamaan batasan umur pernikahan antara laki-laki dan wanita yaitu 19 tahun". Sebagaimana dalam penjelasan Undang-Undang Perkawinan terbaru ini bahwa "batasan umur tersebut dimaksud dinilai telah matang jiwa raganya untuk melangsungkan perkawinan agar dapat merealisasikan tujuan perkawinan secara baik tanpa berakhir perceraian dan mendapat keturunan yang sehat dan berkualitas". 49

Selanjutnya tujuan menaikkan batasan umur perkawinan bagi perempuan dalam Undang-Undang ini adalah mengurangi terhadap resiko pada kematian ibu dan anak serta menghambat laju kelahiran. Di samping juga terpenuhinya hak untuk melangsungkan hidup, tumbuh dan berkembangnya anak termasuk pendampingan orang tua dan memberikan akses bagi anak memperoleh pendidikan yang layak sampai perguruan tinggi. Ini artinya, bahwa tujuan sebagaimana yang ditegaskan dalam Undang-Undang No 16 Tahun 2019 tersebut merupakan upaya pembentuk undang-undang dalam mengangkat harkat dan martabat wanita, mengakhiri ketidakadilan, dan segala bentuk diskriminasi terhadap wanita. Pengaturan batasan umur perkawinan dengan segala tujuan yang positif tersebut hakikatnya adalah memberikan jaminan keadilan, kepastian, dan kemanfatan dari tujuan hukum itu diciptakan.

Melihat tujuan kebijakan hukum sebagaimana dijelaskan di atas, secara filosofis dapat dikatakan sejalan dengan substansi hukum Islam (maqashid

\footnotetext{
${ }^{47}$ Undang Undang Dasar Negara Republik Indonesia, "Undang Undang Dasar Negara Republik Indonesia Tahun 1945," 1945.

${ }^{48}$ Muladi, "Hak Asasi Manusia, Hakikat, Konsep Dan Implikasinya dalam Perspektif Hukum Dan Masyarakat”, Refika Aditama, 2009, Bandung, hal. 278.

${ }^{49}$ Undang-Undang Republik Indonesia, "Penjelasan Atas Undang-Undang Republik Indonesia Nomor 16 Tahun 2019 Tentang Perubahan Atas Undang-Undang Nomor 1 Tahun 1974 Tentang Perkawinan," 2019, hal. 2.
} 
syariah) yaitu menciptakan kebaikan (kemaslahatan) sosial kepada manusia pada saat ini dan masa depan. Meskipun dalam hukum Islam sendiri tidak ada ketentuan pasti mengenai ukuran batasan umur yang ideal dalam perkawinan karena itu bersifat ijtihadiyah. Namun hal ini dapat dimengerti bahwa sesungguhnya Islam tidak membolehkan perkawinan usia anak sehingga melahirkan ketidaksetaraan dan diskriminasi. Bahkan menurut Imam Asy-Syakukani dalam wablul Ghamam 'alaa Syifaa'il 'Awaam menyatakan bahwa perkawinan usia anak yang tidak melahirkan kebaikan harus dibatalkan dan lembaga yang berwenang juga berhak membatalkan perkawinan tersebut, anak yang terjebak dalam perkawinan dapat memutuskan perkawinan baik pada saat masih usia anak atau sudah dewasa. ${ }^{50}$

Pendapat sebagaimana diungkapkan oleh para ulama kontemporer tersebut lebih menitikberatkan pada dampak yang ditimbulkan akibat pernikahan usia anak yaitu menghindari kerusakan (mazharat) yang lebih besar dan mendudukkan hukum Islam sebagai aturan yang bersifat humanis dan membawa rahmat bagi seluruh alam. Mardi Candra berpendapat bahwa "salah satu tujuan terpenting dalam hukum Islam yaitu menjaga keturunan. Ketentuan keturunan dalam Islam sesungguhnya menjadi hak anak sehingga anak akan terhindar dari musibah atau menangkis suatu penghinaan yang mungkin akan menimpa dirinya". ${ }^{1}$

Pada prinsipnya Islam sangat memperhatikan konsep keselarasan, keseimbangan, dan kesetaraan tanpa membedakan jenis kelamin, wana kulit, dan etnik. ${ }^{52}$ Konsep tersebut menempatkan pola hubungan antara laki-laki dan wanita adalah sama sejajar sebagai makhluk ciptaan hadapan Allah Swt. Dengan kata lain, Islam menolak dengan tegas segala bentuk diskriminasi sehingga melahirkan pelangaran terhadap hak asasi manusia. Pernyataan ini sejalan dengan pendapat Mahmud Shaltut bahwa "Islam sesungguhnya menempatkan perempuan sebagai mitra bagi kaum laki-laki, sehingga Islam memberikan kesetaraan antara hak dan

\footnotetext{
${ }^{50}$ Badan Pembinaan Hukum Nasional Kemenkumham, "Hasil Penyelarasan Naskah Akademik Rancangan Undang-Undang Tentang Perubahan Atas Undang-Undang Nomor 1 Tahun 1974 tentang Perkawinan", 2019, hal. 34. hal. 75 .

${ }^{51}$ Candra, “Aspek Perlindungan Anak Indonesia: Analisis Tentang Perkawinan Di Bawah Umur,"

${ }^{52}$ Subhan, “Al-Qur'an Dan Perempuan Menuju Kesetaraan Gender Dalam Penafsiran,” hal. 30.
} 
kewajiban bagi laki-laki dan perempuan. Hak-hak tersebut misalnya meliputi menyampaikan pendapat, pendidikan, ibadah dan hak dalam kehidupan lainnya". ${ }^{53}$

Membincang kebijakan hukum perubahan batasan usia perkawinan dalam perspektif hukum Islam sesungguhnya dapat dilihat dari asas dan tujuan dalam penyusunan substansi hukum (materi) oleh pembuat Undang-Undang. Dalam salah satu konsideran Undang-Undang No 16 Tahun 2019 menyatakan bahwa “perkawinan pada usia anak menimbulkan dampak negatif bagi tumbuh kembang anak dan akan menyebabkan tidak terpenuhinya hak dasar anak seperti hak atas perlindungan dari kekerasan dan diskriminasi, hak sipil anak, hak kesehatan, hak pendidikan, dan hak sosial anak" ${ }^{54}$ Pernyataan tersebut dapat kita pahami sebagai upaya pemerintah untuk melindungi institusi perkawinan dalam rangka memewujudkan kemaslahatan yaitu menjaga keberadaan jiwa, keturunan, dan akal sebagaimana dalam konsep maqashid syariah.

Undang-Undang No 16 Tahun 2019 sebagai produk hukum melalui proses legislasi sesungguhnya secara subtanstif dan esensi sejalan dengan asas-asas atau prinsip-prinsip dalam hukum Islam. Untuk mengakhiri tulisan sederhanan ini bahwa pada intinya hukum yang baik dalam sebuah negara adalah hukum yang dapat diterima oleh semua kalangan, oleh karenanya dalam setiap pembentukan peraturan hukum sudah seharusnya memperhatikan kebutuhan hukum dalam masyarakat, nilai-nilai dan norma yang berkembang sehingga tidak terjadi pertentangan dan pada tataran pelaksanaannya dapat berjalan secara efektif, di samping dibutuhkan juga kesadaran masyarakat dalam mentaati hukum.

\section{E. PENUTUP}

Batasan umur dalam perkawinan hakikatnya merupakan unsur penting dalam merealisasikan sebuah tujuan perkawinan. Hasil kajian penelitian ini menunjukkan bahwa umur perkawinan dalam hukum Islam para ulama fikih berbeda pendapat hal tersebut dikarenakan Al-Qur'an sebagai sumber utama hukum Islam tidak menjelaskan secara gamblang mengenai batasan umur dalam perkawinan. Hukum Islam hanya mensyaratkan baligh (memiliki kecakapan dalam melakukan tindakan

\footnotetext{
${ }^{53}$ Subhan, hal. 9.

${ }^{54}$ Undang-Undang Republik Indonesia, "Penjelasan Atas Undang-Undang Republik Indonesia Nomor 16 Tahun 2019 Tentang Perubahan Atas Undang-Undang Nomor 1 Tahun 1974 Tentang Perkawinan"
} 
e-ISSN : 2621-4105

hukum, mampu membedakan antara yang baik dan buruk) sebagai syarat dalam perkawinan. Sedangkan dalam hukum nasional juga terdapat ketidaksergamaan dalam penentuan batasan umur seseorang, salah satu faktor yang melatarbelakangi adalah lemahnya koordinasi dan pelibatan berbagai pihak dalam pembentukan peratuan perundang-undangan. Kebijakan hukum dalam pembentukan Undang-Undang No 1 Tahun 1974 pada hakikatnya diarahkan untuk mengadakan unifikasi hukum dalam permasalahan hukum pernikahan yang beragam dan berlaku bagi masyarakat hukum Indonesia tanpa menghilangkan kebhinekaan yang ada. Dan pengaturan perubahan batasan minimal perkawinan dengan menyamakan umur laki-laki dan wanita adalah 19 tahun sesungguhnya diarahkan dalam rangka mengangkat harkat dan martabat perempuan, mengembalikan hak-hak sesuai konstitusional serta sebagai upaya preventif terjadinya pernikahan anak yang berpotensi terhadap eksploitasi anak yang marak terjadi beberapa tahun belakangan. Kebijakan hukum perubahan batasan minimal umur perkawinan dalam pandangan hukum Islam dapat dikatakan bernilai kemaslahatan yaitu menjaga, jiwa, keturunan, dan akal sebagaimana tercermin dari konsideran Undang-Udanng Nomor 16 Tahun 2019 tentang Perkawinan.

\section{DAFTAR PUSTAKA}

\section{Buku}

Abror, Khoirul. "Hukum Perkawinan Dan Perceraian.", Ladang Kata, 2020, Yogyakarta.

Badan Pembinaan Hukum Nasional Kemenkumham. "Hasil Penyelarasan Naskah Akademik Rancangan Undang-Undang Tentang Perubahan Atas Undang-Undang Nomor 1 Tahun 1974 Tentang Perkawinan," 2019, Jakarta.

Candra, Mardi. “Aspek Perlindungan Anak Indonesia: Analisis Tentang Perkawinan Di Bawah Umur.”, Kencana, 2018, Jakarta.

Gani, Burhanuddin ABD. "Perubahan Batas Usia Kawin Dalam Putusan Mahkamah Konstitusi Nomor 22/PUU-XV/2017 Di Lihat Dari Penerapan Maqasid AsySyari'ah. ”, LKKI Publisher Fakultas Syariah dan Hukum, Universitas Islam Negeri Ar-Raniry, 2020, Banda Aceh.

Mubarok, Jaih. "Pembaharuan Hukum Perkawinan Di Indonesia”, Simbiosa Rekatama Media, 2015, Bandung.

Muladi. "Hak Asasi Manusia, Hakikat, Konsep Dan Implikasinya Dalam Perspektif Hukum Dan Masyarakat.”, Refika Aditama, 2009, Bandung.

Munti, Ratna Batara dan Hindun Anisah. "Posisi Perempuan Dalam Hukum Islam di Indonesia. ”, LKiS, 2005, Yogyakarta.

Nuruddin, Amiur, and Azhari Akmal Tarigan. "Hukum Perdata Islam Indonesia: Studi 
e-ISSN : 2621-4105

Kritis Perkembangan Hukum Islam dari Fikih, Undang-Undang Nomor 1 Tahun 1974 Sampai Kompilasi Hukum Islam.”, Kencana, 2006, Jakarta.

Statistik, Badan Pusat, and UNICEF Indonesia. "Perkawinan Usia Anak Di Indonesia 2013 Dan 2015." Revisi, Badan Pusat Statistk dan UNICEF Indonesia, 2017, Jakarta.

Subhan, Zaitunah. "Al-Qur'an Dan Perempuan Menuju Kesetaraan Gender Dalam Penafsiran.”, Kencana, 2015, Jakarta.

Syarifuddin, Amir. "Hukum Perkawinan Islam Di Indonesia; Antara Fiqh Munakahat Dan Undang-Undang Perkawinan.”, Kencana, 2009, Jakarta.

\section{Jurnal}

Asnawi, Habib Shulton. "Tinjauan Kritis Terhadap Hak-Hak Perempuan dalam UU. No. 1 Tahun 1974 tentang Perkawinan: Upaya Menegakkan Keadilan dan Perlindungan HAM Perspektif Filsafat Hukum Islam” Jurnal Fikri 1 (1), 2016.

Aristoni, and Junaidi Abdullah. "4 Dekade Hukum Perkawinan Di Indonesia : Menelisik Problematika Hukum Dalam Perkawinan Di Era Modernisasi” Yudisia 7 (1), 2016.

Christian, Jordy Herry, and Kirana Edenela. "Terampasnya Hak-Hak Perempuan Akibat Diskriminasi Batas Usia Perkawinan”,Lex Scientia Law Review 3 (1), 2019.

Hidayat, Fatah. "Dinamika Perkembangan Hukum Keluarga di Indonesia”, Jurnal An Nisa'a 9 (2), 2014.

Hidayatulloh, Ilham, Retno Putri, Ter Naotrue, Riswanda, and Muhammad Fedryansyah. "Persepsi Perkawinan Usia Dini dan Pemberdayaan Gender (Studi Kasus Desa Pancawati Kecamatan Caringin Kabupaten Bogor) 'Sosioglobal : Jurnal Pemikiran dan Penelitian Sosiologi 3 (1), 2018. https://doi.org/10.24198/jsg.v3i1.18148.

Indrawati, Septi, and Agus Budi Santoso. "Perspektif Undang-Undang Nomor 16 Tahun 2019 Tentang Perkawinan Terhadap Batas Usia Melakukan Perkawinan”, AMNESTI Jurnal Hukum 2 (1), 2020.

Lestari, Novita. "Problematika Hukum Perkawinan di Indonesia." Jurnal Ilmiah Mizani: Wacana Hukum, Ekonomi dan Keagamaan 4 (1), 2018 https://doi.org/10.29300/mzn.v4i1.1009.

Mubarok, Nafi. "Sejarah Hukum Perkawinan Islam di Indonesia”, Al-Hukama 2(2), (2012).

Maula, Bani Syarif. "Perlindungan Perempuan Dalam Hukum Perkawinan Di Indonesia: Wacana Pembaharuan Undang-Undang Perkawinan Dalam Masalah Batas Usia Perkawinan”, Jurnal Studi Islam, Gender dan Anak 14 (1), 2019 https://doi.org/10.24090/yinyang.v14i1.2019.pp14-38.

Rifai, Ahmad, Ibnu Sodiq, and Abdul Muntholib. "Sejarah Undang-Undang Perkawinan Atas Pendapat Hingga Pertentangan dari Masyarakat Dan Dewan Perwakilan Rakyat Tahun 1973-1974”, Journal of Indonesian History 4 (1), 2015.

Sanawiah, and Muhamad Zainul. "Batasan Kedewasaan Dan Kecakapan Hukum Pewasiat Menurut KHI Dan KUH Perdata”, Jurnal Hadratul Madaniyah 5 (1), 2018.

Shafiyullah. "Hak Usia Perkawinan Bagi Perempuan (Perspektif Hukum Islam Dan Gender)", YINYANG Jurnal Studi Islam, Gender, dan Anak10 (1), 2015. http://www.ejournal.iainpurwokerto.ac.id/index.php/yinyang/article/view/1219.

Sholehudin, Miftahus. "Legislasi Pendewasaan Usia Perkawinan Alternatif Perpsektif Hukum Adat Dalam Pembangunan Hukum Nasional”, Jurnal Hukum Samudra 
e-ISSN : 2621-4105

Keadilan 14(1), 2019.https://doi.org/10.33059/jhsk.v14i1.1081.

Susetyo, Heru. “Revisi Undang-Undang Perkawinan”, LexJurnalica 4, no. 2 (2007).

Yusuf. "Dinamika Batasan Usia Perkawinan di Indonesia: Kajian Psikologi Dan Hukum Islam”, JIL: Journal of Islamic Law 1 (2), 2020. https://doi.org/10.24260/jil.v1i2.59.

\section{Peraturan Perundang-undangan}

Undang Undang Dasar Negara Republik Indonesia Tahun 1945

Undang-Undang Republik Indonesia Nomor 1 Tahun 1974 tentang Perkawinan

Undang-Undang Republik Indonesia Nomor 16 Tahun 2019 tentang Perubahan Atas Undang-Undang Nomor 1 Tahun 1974 Tentang Perkawinan

Undang-Undang Republik Indonesia Nomor 35 Tahun 2014 tentang Perubahan Atas Undang-Undang Nomor 23 Tahun 2002 Tentang Perlindungan Anak

Instruksi. Instruksi Presiden Nomor 1 Tahun 1991 tentang Kompilasi Hukum Islam

\section{Disertasi}

Hermanto, Agus. "Rekontruksi Undang-Undang Perkawinan Di Indonesia Dan Keadilan Gender”,Disertasi, Program Pasca Sarjana, Institut Agama Islam Negeri Raden Intan Lampung, 2017, Lampung.

\section{Internet}

http://pa-blitar.go.id/pablweb/informasi-pengadilan/160-untuk-kepentingan-apabatasan-usia-dewasa-itu.html. 